\title{
PHOSPHORUS SORPTION IN RELATION TO SOIL GRAIN SIZE AND GEOCHEMICAL COMPOSITION IN THE SIMIYU AND KAGERA RIVER BASINS, TANZANIA.
}

\author{
RA Tamatamah \\ Department of Fisheries Science and Aquaculture, University of Dar es Salaam, P.O. Box 35064, \\ Dar es Salaam, Tanzania.E-mail:rtamah@cc.udsm.ac.tz
}

\begin{abstract}
The phosphorus sorption characteristics of eight surface soil samples representative of the land use and landscape in the Simiyu and Kagera River basins were determined using the Langmuir equation. The Langmuir $P$ adsorption maximum $\left(C_{\text {max }}\right)$ ranged from 109 to $802 \mathrm{mg} \mathrm{kg}^{-1}$, while Langmuir coefficient $(K)$ ranged from 59 to $736 \mathrm{mg} \mathrm{L}^{-1}$. $C_{\text {max }}$ and were positively correlated to clay content, aluminium ( $\mathrm{Al}$ ), and iron ( $\mathrm{Fe}$ ) and negatively correlated to calcium (Ca). By using stepwise regression, the combination of Al, Fe, clay and Ca predicted more than $94 \%$ of the variation in the P sorption capacity of soils samples from Simiyu and Kagera basins. These four soil properties, which are strongly related to $P$ sorption, could therefore be used as quick tests for predicting the P sorption capacity of soils in the two basins.
\end{abstract}

\section{INTRODUCTION}

The chemistry of phosphorus $(\mathrm{P})$ in soils is important because adequate availability of $\mathrm{P}$ is required for plant growth and production. However, in recent decades soil erosion by runoff and/or leaching of $\mathrm{P}$ from agricultural soils have been reported to contribute to eutrophication of freshwater bodies (Sanyal \& De Datta 1991, Sharpley \& Gburek 1998, Tamatamah 2004). For example, around Lake Victoria catchment, runoff is identified as the second major source of $\mathrm{P}$ input, on average, contributing about $40 \%$ of the annual total phosphorus loading to the lake (Tamatamah et al. 2005). A post-1960's three-fold increase of $\mathrm{P}$ concentration in the waters of Lake Victoria is linked to the general eutrophication of this large tropical lake (Hecky 1993).

For runoff transport, $\mathrm{P}$ is generally transferred from catchments to the lake through erosion of catchment soils which are then delivered to the lake as river sediments. In this regard, it is the ability of soils and sediments to sorb $\mathrm{P}$ which is considered to be the main factor determining dissolved phosphate concentrations in freshwaters (Shukla et al. 1971, Froelich 1988). Although $\mathrm{P}$ sorption experiments were initially developed to determine $\mathrm{P}$ fertilizer requirements in agricultural soils (Fox \& Kamprath 1970), they are now widely used in environmental studies to identify soils (or sediments) likely to have environmental impact on water quality (Sharpley et al. 1996, Sakadevan \& Bavor 1998). An alternative approach for estimating $\mathrm{P}$ sorption capacity has included the determination of key soil properties that influence $\mathrm{P}$ sorption i.e. hydrous oxides of $\mathrm{Fe}$ and $\mathrm{Al}$, particle size distribution, and $\mathrm{pH}$. These efforts have yielded empirical models that have been used successfully to predict $\mathrm{P}$ sorption capacity of soils in Europe (Vander Zee \& Van Riemsdijk 1988), Australia (Singh \& Gilkes 1991) and tropical Africa (Adetunji 1997).

The overall goal of this study was to determine if easily and routinely measured physical and chemical properties of soil could be used to identify catchment soils with significant potential for nonpoint $\mathrm{P}$ pollution of surface waters in the Simiyu and Kagera basins of the Lake Victoria watershed. This goal was pursued by 1) determining the particle size distribution and geochemical composition of soils obtained from representative locations in the Simiyu 
and Kagera basins; 2) quantifying $\mathrm{P}$ sorption capacities of these soils; and 3) relating $\mathrm{P}$ adsorption capacity with soil particle size and geochemical composition in order to determine principal factors associated with $\mathrm{P}$ sorption.

\section{MATERIALS AND METHODS \\ Basins description}

The study was conducted in the Simiyu and Kagera basins located in the south and south-western parts of Lake Victoria in Tanzania (Figure 1). The study sites represent a wide range of land uses commonly found in the Lake Victoria watershed. Shifting cultivation (made possible by deforestation) and grazing on the fallow land of shifting cultivation are among the common land use practices in the basins (Kudhongania et al. 1996).

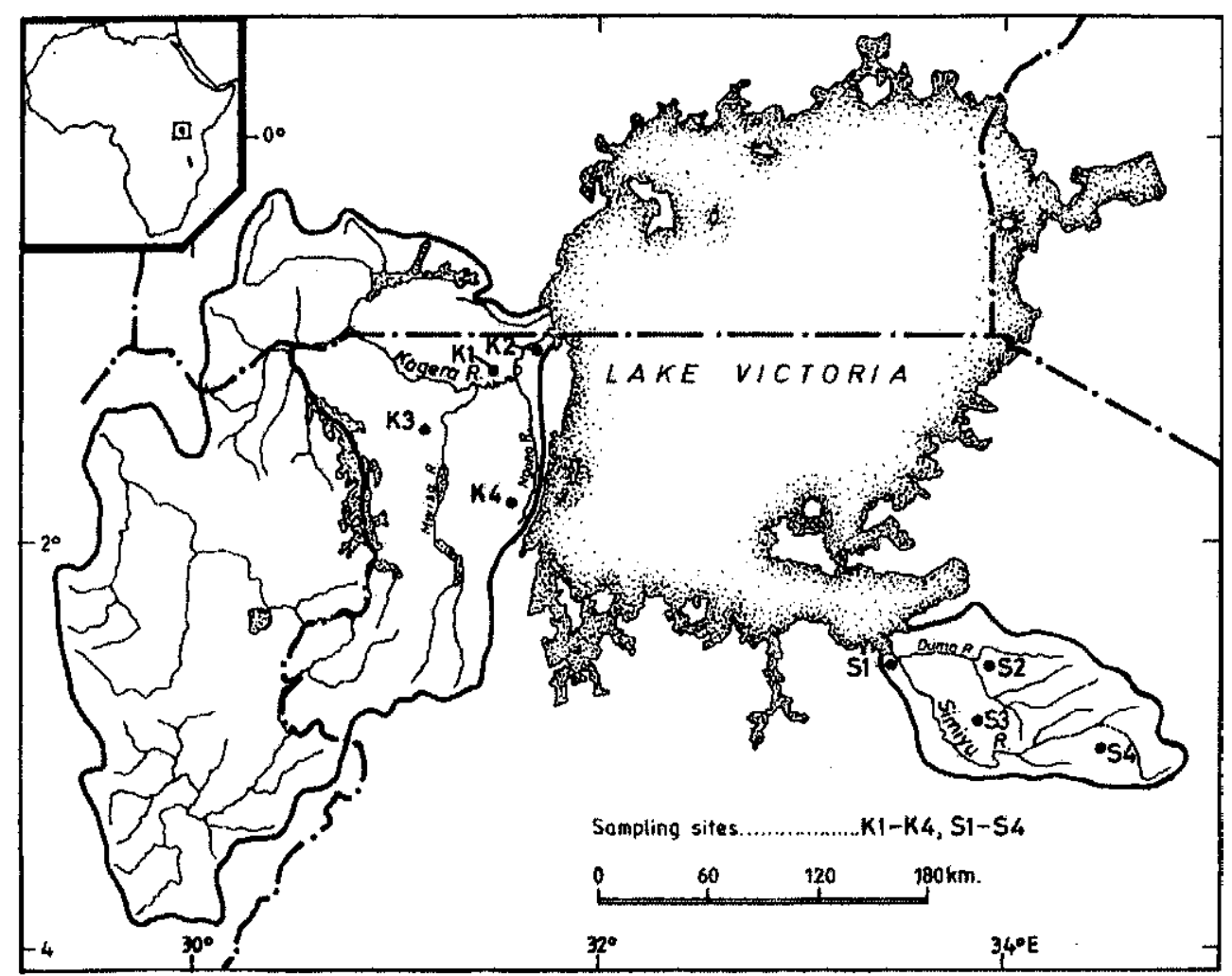

Figure 1: $\quad$ Map of the study area showing soil sampling sites in the Simiyu (S) and Kagera (K) basins.

Sample collection, treatment and analyses Surface soil samples to a $10-\mathrm{cm}$ depth were collected in triplicate from eight sites (Figure 1) based on factors such as land use, soil type, slope, and proximity or accessibility to surface water drainage network. These factors were considered to ensure that a variety of typical landscapes were sampled in each study basin. The top soil (10-cm depth) was used because it is in direct contact with runoff waters and more likely to be eroded during heavy storms, hence a larger and more direct impact on $\mathrm{P}$ concentration in basin rivers and the lake. The soil samples from each sampling location were composited by mixing $500 \mathrm{~g}$ 
of the three sub-samples, air dried, ground, sieved to $2 \mathrm{~mm}$ mesh, and packed in airtight plastic bags. Soil samples in sealed airtight bags were taken to the soil science laboratory at the Sokoine University of Agriculture (Morogoro) for determination of $\mathrm{P}$ sorption capacity, $\mathrm{pH}$ and soil grain size distribution. Sub-samples were also taken to Southern and Eastern Africa Mineral Centre - SEAMIC (Dar es Salaam) where soil geochemical compositions were determined.

Particle size distribution was determined by the hydrometer method (Bouyoucos 1962). Soil $\mathrm{pH}$ was measured with a glass electrode in a 1:2.5 (w/v) substrate/water mixture after equilibration for 30 minutes. Geochemical compositions (major elements - Al, Fe, Ca, $\mathrm{Na}$ and $\mathrm{K}$ ) of the soil samples were determined by X-ray fluorescence spectrometry and the results reported as percent dry weight.

The P sorption experiments were conducted by adding $3 \mathrm{~g}$ of air-dried soil in $50 \mathrm{ml}$ centrifuge tubes containing $30 \mathrm{ml}$ of a series of equilibrating $\mathrm{P}$ concentrations $(0,100$, 200, 300, 400, 500, and $600 \mathrm{mg} \mathrm{l}^{-1}$ ). The equilibrations were performed in triplicate. To reduce the effect of unequal ionic concentrations, $0.5 \mathrm{ml}$ of $0.01 \mathrm{M} \mathrm{CaCl}_{2}$ was added to each centrifuge tube. Two drops of toluene were similarly added to minimize potential bacterial uptake of $\mathrm{P}$ during the equilibration period. The tubes were sealed, placed in a reciprocal platform shaker and shaken for a 30-minute period twice daily for six days at room temperature $(26.5 \pm$ $2^{\circ} \mathrm{C}$ ). At the end of the equilibration period the samples were centrifuged for 5 minutes at $3000 \mathrm{rpm}$ and then filtered through a precombusted Whatman GF/C filter $(\sim 0.45$ $\mu \mathrm{m})$. The filtrates were colorimetrically analyzed for $\mathrm{P}$ at $882 \mathrm{~nm}$ using the ascorbic acid method (Parsons et al. 1984).

The adsorption characteristics of the soils were evaluated by the nonlinear form of the Langmuir adsorption equation:

$$
P_{a d s}=\alpha+\frac{C_{\max } *[P]}{k+[P]}
$$

where $\alpha$ is the $y$-intercept, $P_{a d s}$ is the amount of $\mathrm{P}$ absorbed, $C_{\max }$ is the adsorption capacity, $k$ is a constant and [P] is the $\mathrm{P}$ concentration in water (Stumm \& Morgan 1981). The fitness test of the $P$ sorption data to the Langmuir adsorption equation was performed using the nonlinear regression procedure of SYSTAT statistical package. Differences in Langmuir adsorption coefficients $C_{\max }$ and $k$ among soil samples from the two catchments were assessed using analysis of variance (ANOVA) followed by the least significance difference (LSD) test where significant differences were observed at $\mathrm{p}<0.05$.

\section{RESULTS AND DISCUSSION \\ Soil characteristics}

The $\mathrm{pH}$, particle size distribution, and concentration of major elements determined from soils collected in the two basins are presented in Table 1. Soil $\mathrm{pH}$ ranged from acidic to mildly basic, with two samples from the Kagera basin having $\mathrm{pH}$ values of less than 5.0 and one sample from the Simiyu basin with $\mathrm{pH}$ value of more than 8.0. The clay content $(<2 \mathrm{~m})$ of the soils ranged from 1 to $36 \%$, indicating that samples from the two basins were composed of coarse textured soils. The higher clay contents were for soils K2 and S2.

Relatively higher values of $\mathrm{Al}$ and $\mathrm{Fe}$ were also recorded in soil samples $\mathrm{K} 2$ and $\mathrm{S} 2$. The values of $\mathrm{Al}$ and $\mathrm{Fe}$ recorded in this study fall in the same range as reported for the West Lake Region of Tanzania (Møberg 1973), but are lower than values reported by Msanya et al. (2003) for some benchmark soils of Morogoro district in Tanzania. The analysis of variance showed that there were no significant inter-basin differences ( $\mathrm{p}<$ $\left.0.87 ; F=0.44 ; R^{2}=0.06\right)$ in the values of selected soil properties measured in this study. 
Tamatamah - Phosphorus sorption in relation to soil grain size ...

Table 1: $\quad$ Means (and percent standard deviation) of selected soil properties in the Simiyu (S) and Kagera $(\mathrm{K})$ basins.

\begin{tabular}{llllllllll}
\hline Sample & \multicolumn{3}{c}{ Particle size } & \multicolumn{5}{c}{$\%$ dry weight } \\
\cline { 2 - 9 } & $\begin{array}{c}\text { Sand } \\
\end{array}$ & \% Silt & \% Clay & $\mathrm{pH}$ & $\mathrm{Al}_{2} \mathrm{O}_{3}$ & $\mathrm{Fe}_{2} \mathrm{O}_{3}$ & $\mathrm{CaO}$ & $\mathrm{Na}_{2} \mathrm{O}$ & $\mathrm{K}_{2} \mathrm{O}$ \\
\hline $\mathrm{S} 1$ & 65.20 & 8.40 & 26.40 & 7.5 & 7.05 & 2.87 & 0.23 & 0.35 & 1.07 \\
& $(3.00)$ & $(6.79)$ & $(10.10)$ & $(6.67)$ & $(3.83)$ & $(8.00)$ & $(8.69)$ & $(5.71)$ & $(10.0)$ \\
$\mathrm{S} 2$ & 59.80 & 11.30 & 28.90 & 6.8 & 7.92 & 3.96 & 0.14 & 0.64 & 1.63 \\
& 2.84 & $(8.76)$ & $(2.94)$ & $(8.82)$ & $(5.80)$ & $(3.28)$ & $(7.14)$ & $(13.13)$ & $(3.68)$ \\
$\mathrm{S} 3$ & 79.30 & 6.30 & 14.40 & 8.7 & 6.85 & 3.21 & 0.81 & 1.47 & 3.67 \\
& $(3.75)$ & $(6.67)$ & $(5.90)$ & $(6.90)$ & $(6.42)$ & $(6.23)$ & $(12.47)$ & $(4.10)$ & $(8.99)$ \\
$\mathrm{S} 4$ & 86.00 & 4.40 & 9.60 & 7.3 & 3.52 & 0.92 & 1.43 & 1.04 & 2.19 \\
& $(0.00)$ & $(3.18)$ & $(5.94)$ & $(8.36)$ & $(4.83)$ & $(3.26)$ & $(4.19)$ & $(12.50)$ & $(8.22)$ \\
$\mathrm{K} 1$ & 69.20 & 11.50 & 19.30 & 4.8 & 5.57 & 2.33 & 1.40 & 0.21 & 0.81 \\
& $(5.84)$ & $(6.17)$ & $(5.13)$ & $(8.54)$ & $(6.64)$ & $(6.44)$ & $(6.42)$ & $(9.52)$ & $(4.94)$ \\
$\mathrm{K} 2$ & 41.00 & 23.00 & 36.00 & 4.6 & 11.61 & 5.45 & 0.09 & 0.13 & 0.42 \\
& $(3.240$ & $(6.20)$ & $(4.71)$ & $(6.78)$ & $(12.29)$ & $(5.02)$ & $(3.35)$ & $(10.00)$ & $(5.49)$ \\
$\mathrm{K} 3$ & 78.70 & 9.20 & 12.10 & 5.9 & 6.98 & 3.78 & 0.69 & 0.10 & 0.91 \\
& $(3.24)$ & $(6.20)$ & $(4.71)$ & $(6.78)$ & $(12.29)$ & $(8.47)$ & $(4.35)$ & $(10.00)$ & $(5.49)$ \\
$\mathrm{K} 4$ & 96.50 & 2.3 & 1.20 & 7.0 & 2.72 & 0.64 & 1.72 & 1.04 & 3.44 \\
& $(1.32)$ & $(6.10)$ & $(11.67)$ & $(5.71)$ & $(4.78)$ & $(7.81)$ & $(10.50)$ & $(11.50)$ & $(9.10)$ \\
\hline
\end{tabular}

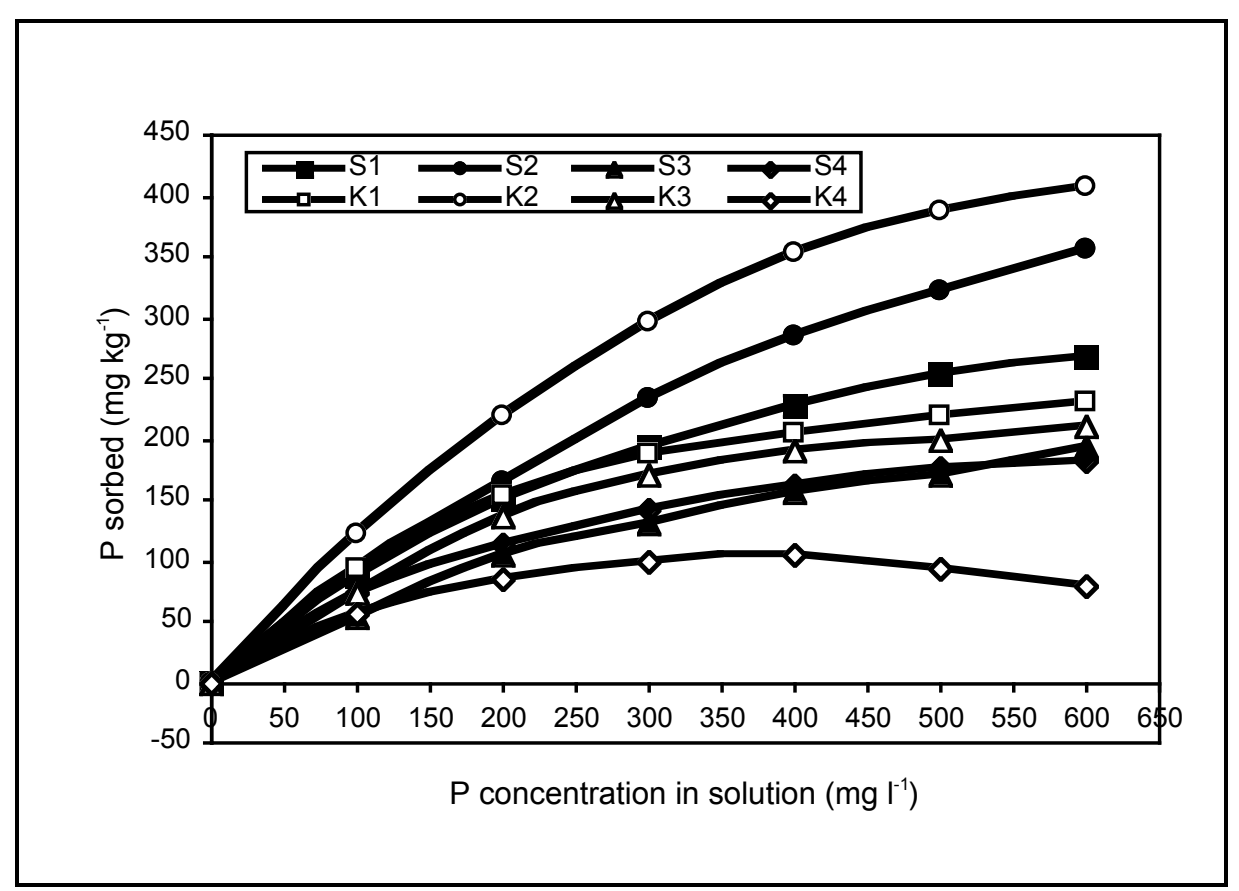

Figure 2: $\quad$ Phosphorus sorption isotherms for soil samples in the Simiyu (S) and Kagera (K) basins 


\section{Phosphorus sorption}

The P sorption isotherms for soil samples from the two basins are shown in Figure 2. Generally, the samples had low to medium $\mathrm{P}$ sorption capacities, with most soils attaining their maximum sorption capacities at equilibrium concentration of $500 \mathrm{mg} \mathrm{l}^{-1}$. However, for soil samples $\mathrm{K} 2$ and $\mathrm{S} 2$ maximum sorptions were not attained even at equilibrium concentration of $600 \mathrm{mg} \mathrm{l}^{-1}$. $\mathrm{K} 2$ and S2 had relatively higher $\mathrm{Al}, \mathrm{Fe}$ and clay contents than other soil samples.

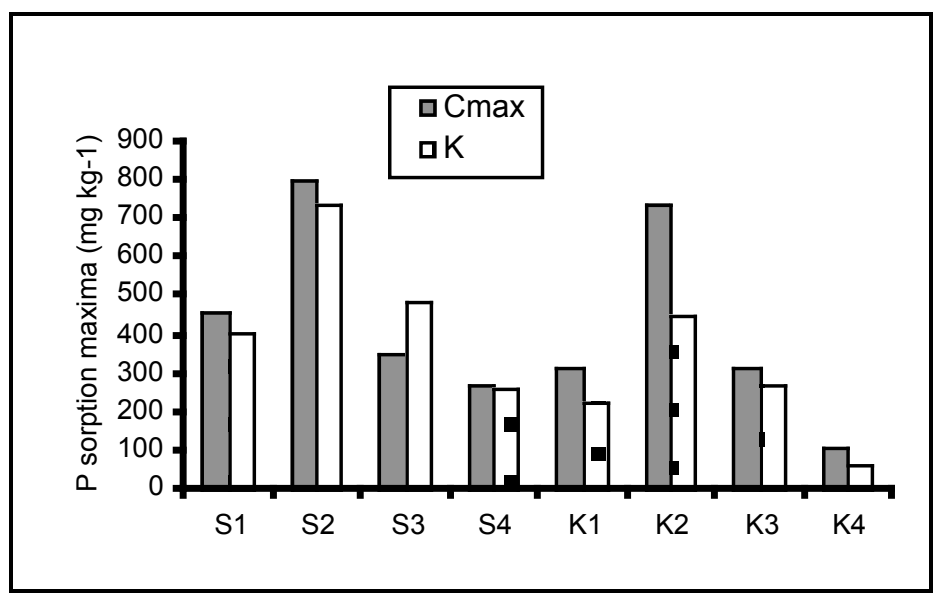

Figure 3: $\quad$ Phosphorus sorption maxima $\left(\mathrm{C}_{\max }\right)$ and adsorption energy $(\mathrm{K})$ for soil samples in the Simiyu and Kagera basins.

Table 2: $\quad$ Estimates of Langmuir coefficients ( $\alpha, \mathrm{Cmax}$, and $\mathrm{K}$ ) and fitting coefficients of sorption data to Langmuir equation

\begin{tabular}{lcccccccc}
\hline $\begin{array}{l}\text { Langmuir } \\
\text { Coefficient }\end{array}$ & \multicolumn{4}{c}{ Simiyu River } & \multicolumn{5}{c}{ Kagera River } \\
\cline { 2 - 9 } & $\mathrm{S} 1$ & $\mathrm{~S} 2$ & $\mathrm{~S} 3$ & $\mathrm{~S} 4$ & $\mathrm{~K} 1$ & $\mathrm{~K} 2$ & $\mathrm{~K} 3$ & $\mathrm{~K} 4$ \\
\hline$\alpha\left(\mathrm{mg} \mathrm{kg}^{-1}\right)$ & -1.32 & -1.73 & -1.20 & -2.32 & -1.97 & -3.62 & -3.09 & -2.76 \\
$C_{\max }\left(\mathrm{mg} \mathrm{kg}^{-1}\right)$ & 456.65 & 802.15 & 346.73 & 267.84 & 319.47 & 738.05 & 314.77 & 108.96 \\
$K\left(\mathrm{mg} \mathrm{l}^{-1}\right)$ & 408.55 & 735.81 & 487.48 & 257.44 & 222.51 & 453.41 & 266.35 & 59.20 \\
$R^{2}$ & 0.99 & 0.99 & 0.99 & 0.99 & 0.99 & 0.99 & 0.98 & 0.92 \\
\hline
\end{tabular}

Figure 3 shows the variations in maximum $\mathrm{P}$ sorption capacity $\left(C_{\max }\right)$ and adsorption energy coefficient $(K)$ for the soil samples in the Simiyu and Kagera basins. $C_{\max }$ and $K$ ranged from 109 to $802 \mathrm{mg} \mathrm{kg}^{-1}$ and 59 to $736 \mathrm{mg} \mathrm{l}^{-1}$ for soil samples $\mathrm{K} 4$ and $\mathrm{S} 2$, respectively. ANOVA confirmed that there were significant differences in Langmuir adsorption coefficients $C_{\max }$ and $K$ among soil samples from the two catchments $(P<$ $\left.0.001 ; F=12.09 ; R^{2}=0.91\right)$. A post-hoc test LSD identified soil S2 as having significantly higher $C_{\max }$ and $K$ than soil samples K4, K2, K1, and K3 $(P<0.001-$ $0.016)$. In addition to these results, the $P$ sorption values obtained from $\mathrm{P}$ sorption 
experiment were well described by Langmuir equation with fitting coefficients $\left(R^{2}\right)$ ranging from 0.92 to 0.99 (Table 2).

\section{Phosphorus sorption in relation to soil properties}

For soils from different regions of the world, sorption of $\mathrm{P}$ has been variously related to different forms of $\mathrm{Al}, \mathrm{Fe}$ and clay (Juo \& Fox 1977, Singh \& Gilkes 1991, Yuan \& Lavkulich 1994). For example, Cogger and Duxbury (1984) demonstrated that even small differences in total $\mathrm{Fe}$ and Al contents can make significant differences on ability of soil to sorb or desorb P. They found that as much as $44 \%$ of the fertilizer and mineralized $\mathrm{P}$ in cultivated soil samples low in total $\mathrm{Fe}$ and $\mathrm{Al}$ content $(0.84 \%)$ was lost via leaching relative to $<2 \%$ from soils higher in total $\mathrm{Fe}+\mathrm{Al}(1.9 \%)$. They suggested that sesquioxide content $(\mathrm{Fe}+\mathrm{Al})$ was the best predictor of $\mathrm{P}$ leaching from organic soils.

For this study, Pearson product-moment correlation coefficients (r) were computed to assess the relationships between Langmuir sorption parameters $\left(C_{\max }\right.$ and $\left.K\right)$ and selected soil properties (Table 3). Most of the soil properties were found to have significant correlation with $\mathrm{P}$ sorption. Among these, total $\mathrm{Fe}, \mathrm{Al}, \mathrm{Ca}$ and clay were considered as key parameters controlling $\mathrm{P}$ sorption. Other parameters including $\mathrm{pH}, \mathrm{Na}$ and $\mathrm{K}$ did not have significant influence on P sorption.

Table 3: Coefficients for the relationship between soil properties and Langmuir adsorption coefficients

\begin{tabular}{lcc}
\hline Soil property & $\boldsymbol{C}_{\max }$ & $\boldsymbol{K}$ \\
\hline $\mathrm{pH}$ & -0.283 & 0.159 \\
$\mathrm{Al}_{2} \mathrm{O}_{3}$ & $0.840^{* *}$ & $0.658^{*}$ \\
$\mathrm{Fe}_{2} \mathrm{O}_{3}$ & $0.814^{* *}$ & $0.674^{*}$ \\
$\mathrm{Clay}$ & $0.919^{* *}$ & $0.729 *$ \\
$\mathrm{CaO}$ & $-0.873^{* *}$ & -0.816 \\
$\mathrm{Na}_{2} \mathrm{O}$ & -0.375 & -0.010 \\
$\mathrm{~K}_{2} \mathrm{O}$ & -0.510 & -0.171 \\
\hline
\end{tabular}

These results are consistent with findings reported in other studies where increased concentrations of $\mathrm{Al}$ and $\mathrm{Fe}$ were found to represent oxides and hydroxides associated with the clay minerals kaolinite, illite and pyrophyllite, which serve as a substrate for increased P adsorption (Borggaard 1983, Lopez et al. 1996, Sakadevan \& Bevor 1998). Ellis and Truong (1955) found that montmorillonite clays were unable to fix $\mathrm{P}$ after removal of all $\mathrm{Al}$ and $\mathrm{Fe}$. A negative but significant correlation between the Langmuir P sorption parameters and $\mathrm{Ca}$ can be explained in terms of possible coprecipitation of dissolved $\mathrm{P}$ with calcite formed in situ as reported in other related studies (Murphy et al. 1983, Driscoll et al. 1993). Thus, low adsorption capacity should be found in calcareous soils and sediments (Stauffer 1985).

The observed significant correlation between $\mathrm{P}$ sorption and a number of soil properties does not necessarily mean that all properties control P sorption behaviour, as some of the properties may have some inter-correlation and therefore reflected in their association with P sorption. To check for the possible inter-correlation between soil properties, stepwise multiple regression analyses were computed to obtain the most predictive equations for the $\mathrm{P}$ sorption maximum $\left(\mathrm{P}_{\text {ads }}\right)$ as follows:

$\mathbf{P}_{\text {ads }}=328.61-82.58 \mathrm{Al}+118.52 \mathrm{Fe}+$
19.15 Clay $-82.87 \mathrm{Ca}$ 
where $\mathrm{Al}, \mathrm{Fe}$ and $\mathrm{Ca}$ are expressed in percent dry weight units as determined by XRF spectrometry. The values of $\mathrm{R}^{2}$ for various steps in the calculation of regression equations for different order and combinations of soil properties are given in Table 4. They signify that the selected soil properties (i.e. Al, Fe, Clay and $\mathrm{Ca}$ ) are not inter-correlated as each one of them had a significant contribution to the observed $\mathrm{P}$ sorption characteristics of soils in the two basins. Therefore, for the eight surface soil samples examined in this study $\mathrm{P}$ sorption capacity could be adequately predicted from $\mathrm{Al}, \mathrm{Fe}$, clay and $\mathrm{Ca}$ content $\left(\mathrm{R}^{2}=0.89 ; \mathrm{p}<\right.$ 0.001) (Figure 4).

Table 4: $\quad$ Stepwise correlation equations for predicting $\mathrm{P}_{\mathrm{ads}}$ from soil properties in the Simiyu and Kagera basins.

\begin{tabular}{lllll}
\hline Step & Correlation equation & $R^{2}$ & Correlation equation & $R^{2}$ \\
\hline $\mathrm{I}$ & $\mathrm{Al}$ & 0.840 & $\mathrm{Al}$ & 0.840 \\
II & $\mathrm{Al}+\mathrm{Fe}$ & 0.840 & $\mathrm{Al}+$ Clay & 0.920 \\
III & $\mathrm{Al}+\mathrm{Fe}+\mathrm{Ca}$ & 0.888 & $\mathrm{Al}+\mathrm{Clay}+\mathrm{Ca}$ & 0.933 \\
IV & $\mathrm{Al}+\mathrm{Fe}+$ Clay & 0.938 & $\mathrm{Al}+\mathrm{Clay}+\mathrm{Fe}$ & 0.938 \\
IV & $\mathrm{Al}+\mathrm{Fe}+$ Clay $+\mathrm{Ca}$ & 0.943 & $\mathrm{Al}+\mathrm{Clay}+\mathrm{Fe}+\mathrm{Ca}$ & 0.943 \\
\hline
\end{tabular}

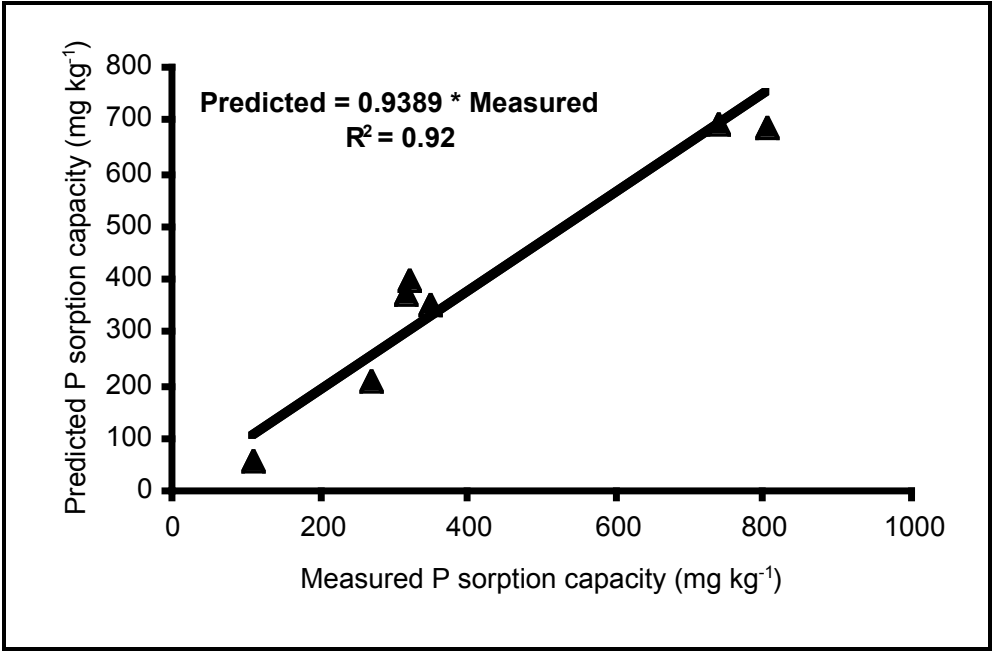

Figure 4: $\quad$ Comparison of predicted and measured P sorption capacity of soils in the Simiyu and Kagera basins. Predicted $\mathrm{P}$ sorption capacity determined from the equation: $[$ Predicted $=328.61-82.58 \mathrm{Al}+118.52 \mathrm{Fe}+19.15 \mathrm{Clay}-82.87 \mathrm{Ca}]$

\section{Study limitations}

The small sample size, clustered nature of the sampling sites, and lack of long-term soil sampling for determination of key soil properties influencing $\mathrm{P}$ sorption are the major limitations of the present study. The soils samples were collected once during November 2000 and from eight sites only in the two river basins. Therefore, there is a possible error in the prediction of $\mathrm{P}$ sorption characteristics caused by small sample size of the soils. Given a possible basin-wide spatial differences in the distribution of soils a relatively large sample size (more sampling sites) would be needed to reduce the expected error associated with limited 
spatial sampling of soils in the two basins. Because eight sampling sites may not be representative of the actual distribution of soils in the study basins, soil properties and $\mathrm{P}$ sorption characteristics determined here should be viewed as the first order approximation of the expected concentrations from the two basins.

\section{CONCLUSION}

Despite the above mentioned limitations, it appears that $\mathrm{Al}, \mathrm{Fe}$ and soil texture (clay content) strongly influences $\mathrm{P}$ sorption capacity of soils in the Simiyu and Kagera basins. These properties can be used to predict the $\mathrm{P}$ sorption capacity and the potential of these soils to transport $\mathrm{P}$ from the two basins to the waters of Lake Victoria which are sensitive to eutrophication (e.g. Tamatamah 2004). The findings from this study are valuable since measurement of soil texture and concentration of major elements are particularly simple (compared to $\mathrm{P}$ sorption experiments) and could routinely be used to test/identify catchment soils with potential for impairment of surface water quality in the two basins as well as Lake Victoria.

\section{ACKNOWLEDGEMENT}

The author is very grateful to the assistance of the Sokoine University of Agriculture and SEAMIC for permission to conduct soil studies at their laboratories. The study was financed by the Lake Victoria Environmental Management Project (LVEMP) through its Support to Riparian Universities Component.

\section{REFERENCES}

Adetunji MT 1997 Phosphorus sorption capacity of low activity clay soils of South Western Nigeria and its usefulness in evaluating phosphorus requirement of rice. Nutrient Cycling and Agroecosystems 47: 181-188

Borggaard OK 1983 The influence of iron oxides on phosphate adsorption by soil. Journal of Soil Science 34: 333-341
Bouyoucos GJ 1962 Hydrometer method improved for making particle size analysisfor soils. Agronomy Journal 54: 464-465

Cogger C and Duxbury JM 1984 Factors affecting phosphorus losses from cultivated organic soils. Journal of Environmental Quality 13: 111-114.

Driscoll CT, Effler SW, Auer MT, Doerr SM and Penn MR 1993 Supply ofphosphorus to the water column of a productive hardwater lake: Controlling mechanisms and management considerations. Hydrobiologia 253: 6172

Ellis R and Truong E 1955 Phosphate fixation by montmorillonite. Soil Science Society of America Proceedings 19: $451-454$

Fox RL and Kamprath EJ 1970 Phosphate sorption isotherms for evaluating the phosphate requirements of soils. Soil Science Society of America Proceedings 34: 902-907

Froelich PN 1988 Kinetic control of dissolved phosphate in natural rivers and estuaries: A primer on the phosphate buffer mechanism. Limnology and Oceanography 33 (4 part 2): 649-668

Hecky RE 1993 The eutrophication of Lake Victoria. Verh. Internat. Verein. Limnol. 25: $39-48$

Juo ASR and Fox RL 1977 Phosphate sorption characteristics of some benchmark soils of West Africa. Soil Science 124 (6): 370-376

Kudhongania AW, Ocenodongo DL and Okaronon JO 1996 Anthropogenic perturbations on the Lake Victoria ecosystem. p. 625-632. In: Johnson \& Odada (eds.), The limnology climatology and paleoclimatology of the East African lakes. Gordon \& Breach Publishers.

Lopez P, Lluch X, Vidal M and Morgu JA 1996 Adsorption of phosphorus on sediments of the Balearic Island (Spain) related to their composition. Estuarine, Coastal and Shelf Science 42: 185-196 
Møberg JP 1973 An edaphological and pedological investigation of the soils in the West Lake region of Tanzania. Dept. of Soils and Agricultural Chemistry, Royal Veterinary and Agricultural University Copenhagen, Denmark.

Msanya BM, Kaaya AK, Araki S, Otsuka $\mathrm{H}$ and Nyadzi GI 2003 Pedological characteristics, general fertility and classification of some benchmark soils of Morogoro District, Tanzania. African Journal of Science and Technology 4(2): 101-112

Murphy TP, Hall KJ and Yesaki I 1983 Coprecipitation of phosphate with calcite in a naturally eutrophic lake. Limnology and Oceanography 28: 58-69

Parsons TR, Maita Y and Lalli CM 1984 A Manual of chemical and biologicalmethods of seawater analysis. Pergamon, Oxford, England.

Sakadevan K and Bavor HJ 1998 Phosphate adsorption characteristics of soils, slags and zeolite to be used as substrates in constructed wetland systems. Water Research 32 (2): 393-399

Sanyal SK and De Datta SK 1991 Chemistry of phosphorus transformation in soils. Advances in Soil Science 16: 1120

Sharpley AN, Daniel TC, Sims JT and Pote DH 1996 Determining environmentally sound soil phosphorus levels. Journal of Soil and Water Conservation 51: 160-166

Sharpley A and Gburek W 1998 Agricultural phosphorus and water quality: Sources, transport and management. Agriculture and Food Science in Finland 7: 297-314
Shukla SS, Syers JK, Williams JDH, Armstrong DE and Harris RF 1971 Sorption of inorganic phosphorus by lake sediments. Soil Science Society of America Proceedings 35: 244-249

Singh B and Gilkes RJ 1991 Phosphorus sorption in relation to soil properties for themajor soil types of south-western Australia. Australian Journal of Soil Research 29: 602-618

Stauffer RE 1985 Relationship between phosphorus loading and trophic state in calcareous lakes of southeast Wisconsin. Limnology and Oceanography 30: 123145

Stumm W and Morgan JJ 1981 Aquatic Chemistry. Wiley-Interscience, New York. 780 p.

Tamatamah RA 2004 Phosphorus sorption characteristics of sediment in the Simiyuand Kagera River basins: implications for phosphorus loading into Lake Victoria. African Journal of Aquatic Science 29(2): 243-248

Tamatamah RA, Hecky RE and Duthie HC 2005 The atmospheric deposition of phosphorus in Lake Victoria (East Africa). Biogeochemistry 73: 325-344

Vander Zee SE and Van Riemsdijk WH 1988 Sorption kinetics and transport of phosphate in sandy soil. Geoderma 38: 293-309

Yuan G and Lavkulich LM 1994 Phosphate sorption in relation to extractable Iron and Aluminum in spodosols. Soil Science Society of America Journal 58:343-346 